\title{
EDUCATION AND FUTURE WORK ATTITUDES OF STUDENTS IN POLAND AND LITHUANIA: A COMPARATIVE ANALYSIS
}

\author{
Vilmante Kumpikaite - Valiūniene \\ Kaunas University of Technology, Lithuania \\ Ewa Rollnik-Sadowska \\ Ewa Glińska \\ Bialystok University of Technology, Poland
}

\begin{abstract}
Increasing the employment among young people is one of the main objectives of the European Union labour market policy. On the one hand, labour market indicators of youths are worse than the ones for the population as a whole. Moreover, the EU countries face NEETs phenomena when young people are not in education, employment and training. Simultaneously, the strong aging process in Europe and demographic changes determine the need for a particular focus on young people who are an important part of future labour force. It is crucial to equip young people with the skills and competencies tailored to the needs of employers, which also would be consistent with the attitudes and expectations of young people. That is why the authors of the paper decided to take into consideration the work and education attitudes of students in two European countries - Poland and Lithuania. These neighbouring EU member states went through comparable historical and political conditions, which influenced their economic situations also in the area of labour market. However, those countries followed different educational reforms. Lithuania implemented basic dual learning and Poland still represents more theoretical orientation in tertiary education.

The research aim of the paper is to identify the differences in education and future work attitudes of Polish and Lithuanian students. Those differences were diagnosed taking into account: an assessment of own skills for a 'dream' job, perceptions of the impact of environmental factors on a future career, as well as a diagnosis of motivators to work.

The chosen research methods were both secondary data analysis as well as realisation of the primary quantitative research among Polish and Lithuanian students. The survey was conducted among 500 students - roughly in half from each country. The comparison showed large similarities in the factors affecting the motivation of students to work as well as some differences in the perception of the impact of the environment on the future career. The biggest differences among students from two countries were identified in the evaluation of skills needed to find employment.
\end{abstract}

Keywords: education and future work attitudes, education and work motivation, skills' assessment, youth's employment, comparative analysis. 
Vilmante Kumpikaite - Valiūniene, Ewa Rollnik-Sadowska, Ewa Glińska. Education and Future Work Attitudes of Students in Poland and Lithuania: a Comparative Analysis

\section{Introduction}

The human capital of young people is a significant element of labour force for European markets. This is mainly because of demographic changes and the strong ageing of European society. On the one hand, Europeans are living longer and healthier lives, and subsequent generations can benefit from longer life spans. However, this spectacular achievement of European societies is accompanied by fertility rates below replacement levels and, in a remarkably large number of countries, far under that level (EC, 2014). In 2013 the fertility rate in the EU ranged from 1.21 in Portugal to 1.99 in France (Eurostat, 2015).

Simultaneously young Europeans are eager to improve their education, competencies and qualifications. Those precious resources of human capital in many European countries with a lower standard of living are tempted by lucrative emigration to the neighbouring states of the European Union with better job offers. It is crucial to analyse the young people's expectations in the area of their educational and professional activity to create such conditions in the domestic economies that would encourage the young generation to acquire knowledge and conduct a professional life in the country.

The authors chose for the analysis two European countries - Poland and Lithuania. Both of them can be treated as transition economies with a lower GDP than the EU average as well as with worse access to well paid vacancies.

These neighbouring EU member states went through comparable historical and political conditions, which influenced their economic situations also in the area of labour market. However, they differently shaped systems of education after 1989 (including higher education).

Lithuania implemented basic dual learning and Poland still represents more theoretical orientation in tertiary education.

The research aim of the paper is to identify the differences in education and future work attitudes of Polish and Lithuanian students. Those differences were diagnosed taking into account: an assessment of own skills for 'dream' job, perceptions of the impact of environmental factors on future career, as well as a diagnosis of motivators to work.

The chosen research methods were both secondary data analysis as well as realisation of the primary quantitative research among Polish and Lithuanian students. The survey was conducted among 500 students - roughly in half from each country.

The research findings may help the state authorities to determine the actions to support both employers in creating jobs more receptive to young people and also the educational units to be prepared for organising s successful transition of their students from education into the working environment. 


\section{The role of attitudes and motivation in the professional life}

Attitudes are evaluative statements - either favourable or unfavourable about objects, people, or events. In literature attitudes have three components: cognition, affect, and behaviour (Breckler, 1984). The cognitive component of an attitude is a description or belief in the way things are. It sets the stage for the more critical part of an attitude-its affective component. Instead, affect is the emotional or feeling segment of an attitude. Finally, affect can lead to behavioural outcomes. The behavioural component of an attitude describes an intention to behave in a certain way toward someone or something.

Attitudes to work are strongly determined by demographic characteristics, and the age is its crucial element. The significant amount of research has been carried out among the people from generations $\mathrm{X}$ and $\mathrm{Y}$ diagnosing their attitudes toward work. The current generation of youths represents another attitude to the educational and professional life compared with their older coworkers. The research findings suggest that large generational gaps exist, particularly when it comes to work attitudes. Young people just entering the workforce, often called GenMe or Millennials, are more likely than their elders to value leisure time over work and to place a premium on rewards such as higher salaries and status (Bryner, 2010).

An analysis of educational and work attitudes is strictly connected with professional activity's motivation, as it is the driving force of personal professional growth and is determined by a complex system of internal and external impulses.

According to Robbins and Judge (2009), motivation is a process producing individual intensity, objectives, and perseverance in an effort to achieve a goal.

Motivation is broadly considered as one of the most important predictors of successful entry into the professional life (Valero, Hirschi 2016; Hirschi et al., 2009; Salmela-Aro, Mutanen, Koivisto, \& Vuori, 2009).

Such a motivation is often connected with personal proactivity. Being proactive is about taking control to make things happen rather than watching things happen. It is a special type of goal-directed behaviour, which is self starting, anticipatory and change-oriented (Bindl \& Parker, 2010). Proactivity is a significant attitude interacting with the professional position. It can enhance workplace performance as well as generate positive outcomes beyond work performance, such as obtaining career satisfaction (Parker et al., 2010).

Work motivation is dependent on many factors which are connected with individuals' personalities as well as their surroundings. Kanfer, Chen, and Pritchard (2008) postulated that progress in work motivation research is needed to have a better understanding of the content of work motivation, an enhanced insight into how motivational constructs and processes operated across the 
working life-span and how the context in which people live and work influences the content and function of work motivation. The analysis of two countries such as Poland and Lithuania with, on the one hand, common legacy and comparable past socio-economic conditions during the transition process but with a slightly different choice of development paths on the other, can be an interesting field for the research of context influence on education and work attitudes.

\section{The labour market situation of young people in Poland and Lithuania}

After analysing Eurostat labour market indicators for young people in Poland and Lithuania, a better situation among the Lithuanians than the Poles can be noticed. In 2014 both a higher unemployment rate of young people aged 15 to 24 (23.9\% in comparison with $19.3 \%$ in Lithuania) and the indicator of young people neither in employment nor in education and training - so called NEET (12\% for Poland and 9.9 for Lithuania) was recorded in Poland. Simultaneously, the employment rates of youths as well as recent graduates were higher in Lithuania $(62.5 \%$ and $80.7 \%$ respectively, for Poland those indicators reached $60.2 \%$ and $75.6 \%$ ).

The labour market situation of young people is determined not only by the potential of labour demand and the number of vacancies but also the abilities of the education system in terms of providing graduates with the skills needed in the labour market. Such perceived efficiency of education is assured by both adequate levels of financing and reasonable systemic solutions. In 2011, the level of annual expenditure on public and private educational institutions per student compared with GDP per capita at the tertiary level of education was slightly higher in Lithuania (39.2\%) in comparison to Poland (38\%) (Eurostat, 2016).

However, those countries represent significant differences in the field of system solution implemented in tertiary education. Lithuania has introduced a series of reforms aimed at the liberalization of higher education. They involved enhancing competition between public and private universities, the implementation of liberal instruments, i.e. students' vouchers ${ }^{1}$, which changed the financing of higher education as well as increasing the importance of practical orientation of students through the dissemination of dual education (Wołkonowski, 2015). At the same time, the Polish system of tertiary education is considered to be academically driven, and hence insufficiently responsive to the diverse needs of the present-day economy and society (Fulton et al., 2007).

\footnotetext{
${ }^{1}$ Public authorities introducing the model of students' vouchers received a chance to adapt a stream of future students, admitting more vouchers on the directions important for the development of the national economy.
} 


\section{The research project description and sample characteristics}

The empirical part of the paper is a fragment of a research project completed by V. Kumpikaite -Valiūniene et al. (2016) between 2014 and 2015. This project included an online survey administered to business, management or administration students from seven countries, however for the needs of this paper only the statistical material containing the results of a survey conducted in Poland and in Lithuania were used. Questionnaires were prepared according to Analoui's (1993) skills description, Wahba \& Bridwell's (1976) and Maslow's motives' presentation (1967) and environment factors described by Daft et al. (1988) in the native language of respondents using the double translation technique. All the instrument are presented in more details by V. Kumpikaite Valiūniene et al. (2016) The questionnaire contained questions which were aimed to ascertain the attitudes of students regarding their future "dream" job. These attitudes were identified through the prism of three elements: an assessment of own skills gained during college applicable to the "dream" job, perceptions of the impact of environmental factors on a future career, as well as a diagnosis of motivators for work in the future. A four point scale was used to describe motives and the environment, where 0 meant "not important at all", 1"little important", 2 - "important", 3 - "very important" with another 4 point scale applied in respect to the assessment of skills gained during college where 0 meant "weak", 1- "average", 2-"good" and 3- "very good". The sample consisted of 530 people with $322(61 \%)$ being students from Lithuania and 208 students from Poland. In both groups women were the majority, with $58.1 \%$ of Lithuanian students and nearly $56 \%$ of Polish students being female.

\section{Research results}

The students taking part in the study were asked to assess their skills in the context of finding desired employment after obtaining a degree. The survey questionnaire presented 16 abilities which in their turn were divided into 4 groups: task related, people related, analytical and self related. The research results indicate that the students rated their people related skills the highest. The largest average scores in this group of skills were attained by: the ability to make contacts (a mean score of 2.35), communicability (2.34), the ability to work in a team (2.31) and self-reliance (2.28). Analytical abilities, those which could help with gaining good employment in the future, were rated relatively high but lower than people related skills. Within this group the abilities which attained the highest scores included: a sense of responsibility (a mean score of 2.33) and ability to solve problems (a score of 2.25). Students rated their self-related abilities as well developed but lower than skills classified into groups mentioned 
above. In this category of abilities, activity gained the highest mean score (2.15). The students' assessments showed that they judged their preparedness for future employment in the context of task related skills as being the lowest. The average score of all three skills in this group: subject specialized knowledge, experience and the application of experience oscillated around the value of 2.0, while specialty experience was ranked the lowest.

Table 1 Assessment of skills learned during studies - mean values

(source: authors' construction)

\begin{tabular}{|c|c|c|c|c|c|c|c|c|c|c|c|c|c|c|c|c|}
\hline \multirow[b]{3}{*}{$\begin{array}{l}\text { Mean } \\
\text { values }\end{array}$} & \multicolumn{16}{|c|}{ Skills } \\
\hline & \multicolumn{4}{|c|}{ Task related } & \multicolumn{4}{|c|}{ People related } & \multicolumn{4}{|c|}{ Analytical } & \multicolumn{4}{|c|}{ Self-related } \\
\hline & 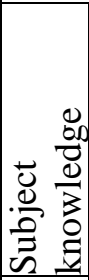 & 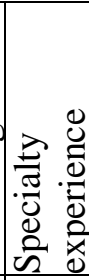 & 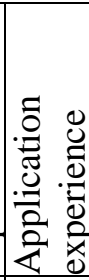 & 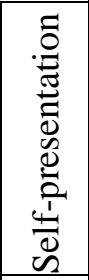 & 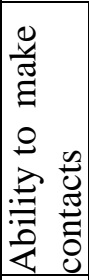 & 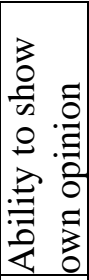 & 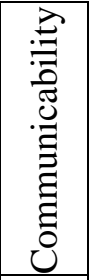 & 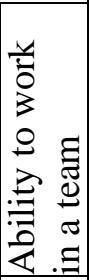 & 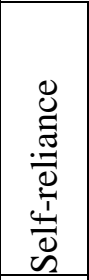 & 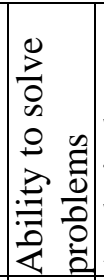 & 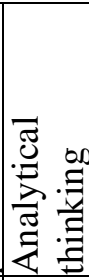 & 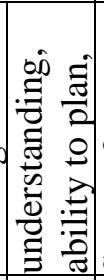 & 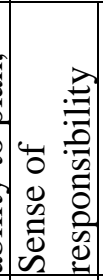 & 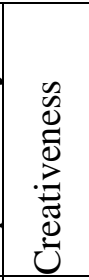 & 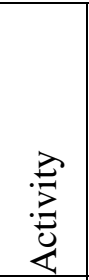 & 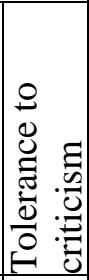 \\
\hline Total & 1.91 & 1.70 & 2.09 & 2.05 & 2.35 & 2.18 & 2.34 & 2.31 & 2.28 & 2.25 & 2.12 & 2.22 & 2.33 & 2.14 & 2.15 & 2.14 \\
\hline Lithuania & 1.97 & 1.37 & 1.77 & 2.12 & 2.31 & 2.25 & 2.27 & 2.30 & 2.17 & 2.18 & 2.11 & 2.26 & 2.16 & 2.06 & 2.11 & 2.47 \\
\hline Poland & 1.85 & 2.02 & 2.41 & 1.98 & 2.39 & 2.11 & 2.41 & 2.32 & 2.40 & 2.32 & 2.13 & 2.18 & 2.50 & 2.23 & 2.18 & 1.82 \\
\hline
\end{tabular}

Significant differences were observed between the group of students from Lithuania and those from Poland in respect to the assessment of skills obtained through their college education needed to gain their "dream" job in the future. The students from Poland value such skills as: application experience, specialty experience, self-reliance, a sense of responsibility and creativeness decidedly higher than their peers from Lithuania. In contrast, the Lithuanian students put a higher worth on tolerance to criticism, subject knowledge and goal understanding in terms of preparation for future employment. Skills rated the highest by the students from Lithuania are: tolerance to criticism, ability to work in a team, and understanding goals, the ability to plan, the capacity to analyze results. The Polish students rate a sense of responsibility, communicability and self-reliance the highest (analytical skills). Specialty experience was given the lowest rating by the respondents from Lithuania. The Polish students felt their tolerance of criticism was their weakest point.

The respondents were asked to select factors related to the environment, which influenced their attitudes toward future professional employment. Among the seven factors included in the study questionnaire (health, family/parents, governmental educational policy, economic situation of the country, political situation of the country, education, experience), the highest average value (2.5) 
was assigned to the factors connected to health and education. The factors concerning experience were gauged to be slightly less significant (an average value of 2.19) but still very important in shaping attitudes toward work. Aspects such as: economic situation of the country (an average value of 1.99) and family (1.91) were assessed to be moderately important in the process of shaping the attitudes of students toward employment. The influence of governmental educational policy (an average value of 1.46) and the political situation of the country (an average value of 1.61) were ranked the lowest.

Table 2 Importance of environmental factors - mean values

(source: authors' construction)

\begin{tabular}{|l|c|c|c|c|c|c|c|}
\hline \multirow{2}{*}{$\begin{array}{c}\text { Mean } \\
\text { values }\end{array}$} & \multicolumn{7}{|c|}{ Environmental factors } \\
\cline { 2 - 8 } & $\begin{array}{c}\text { your } \\
\text { health }\end{array}$ & $\begin{array}{c}\text { family/ } \\
\text { parents }\end{array}$ & $\begin{array}{c}\text { governmental } \\
\text { educational } \\
\text { policy }\end{array}$ & $\begin{array}{c}\text { economic } \\
\text { situation of the } \\
\text { country }\end{array}$ & $\begin{array}{c}\text { political } \\
\text { situation of } \\
\text { the country }\end{array}$ & $\begin{array}{c}\text { education } \\
\text { (back- } \\
\text { ground) }\end{array}$ & experience \\
\hline Total & 2.50 & 1.91 & 1.46 & 1.99 & 1.61 & 2.50 & 2.19 \\
\hline Lithuania & 2.47 & 1.84 & 1.56 & 2.03 & 1.72 & 2.40 & 1.90 \\
\hline Poland & 2.52 & 1.99 & 1.37 & 1.96 & 1.50 & 2.60 & 2.49 \\
\hline
\end{tabular}

The assessment of individual environmental factors regarding the attitudes toward work was quite similar among the students from both Lithuania and Poland, especially in respect to the factors which were deemed as the most important. The students of both countries decided that health and education were the two most important environmental factors influencing their attitudes toward future work. The difference between the students from Poland and Lithuania emerged in defining the third most significant environmental factor. In the opinion of the students from Lithuania, an important role in shaping attitudes toward future work was played by the economic situation of the country. On the other hand, the Polish students stressed the role of experience in constructing their attitudes connected to employment. In the opinions of the students from both countries participating in the study, the least important factor shaping attitudes toward future work is the political situation of the country.

The students participating in the study were asked to indicate the importance of individual factors concerned with motivation in their future workplace. Elements which were considered during the compilation of a list of motivational factors included those meeting basic needs and social needs as well as the need for growth and self-development. Motivational factors were divided into groups. The first set contained an attractive salary and attractive working conditions, while the second consisted of good work atmosphere, an understanding supervisor, good interpersonal relations and the wish to belong to some social group. The third group of factors incorporated a quick career, 
prestige of a workplace, possibility to be promoted, possibility to use your skills and knowledge as well as self-expression. The importance of these elements in a future workplace, as well as the mean values of the answers chosen by all the students participating in the study has been presented in Table 3.

Table 3 Importance of motivation factors - mean values

(source: authors' construction)

\begin{tabular}{|c|c|c|c|c|c|c|c|c|c|c|c|}
\hline \multirow{3}{*}{$\begin{array}{l}\text { Mean } \\
\text { values }\end{array}$} & \multicolumn{11}{|c|}{ Motivation factors } \\
\hline & \multicolumn{2}{|c|}{ Basic needs } & \multicolumn{4}{|c|}{ Social needs } & \multicolumn{5}{|c|}{ Growth needs } \\
\hline & 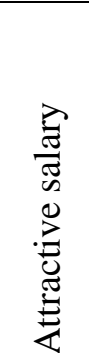 & 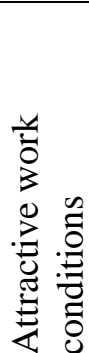 & 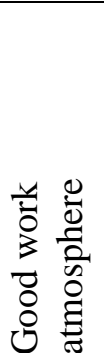 & 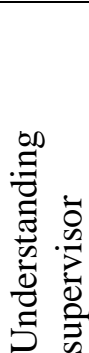 & 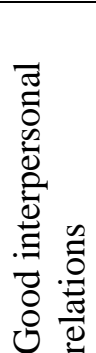 & 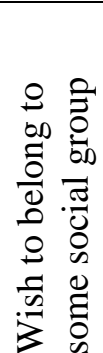 & 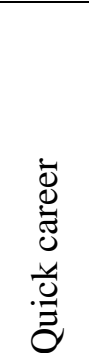 & 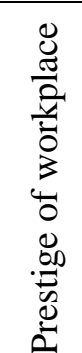 & 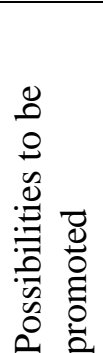 & 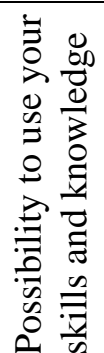 & 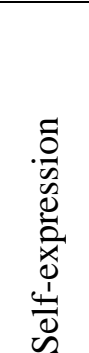 \\
\hline Total & 2.66 & 2.66 & 2.57 & 2.34 & 2.35 & 1.37 & 1.37 & 1.79 & 2.12 & 2.47 & 2.16 \\
\hline Lithuania & 2.63 & 2.66 & 2.60 & 2.41 & 2.38 & 1.55 & 1.86 & 1.87 & 2.54 & 2.60 & 2.37 \\
\hline Poland & 2.69 & 2.66 & 2.54 & 2.27 & 2.33 & 1.19 & 1.67 & 1.71 & 1.69 & 2.34 & 1.94 \\
\hline
\end{tabular}

Looking at the average scores produced by the students, material aspects (those fulfilling basic needs) connected with future work turned out to be the most important group of motivational factors. The results of the research showed that within the group of social motivational factors, the element connected with good working atmosphere (a mean score of 2.57) as well as the related factor of good interpersonal relations at work (an average of 2.35) were especially highly regarded. Another social motivational factor which was a very significant motivator for students was to have an understanding supervisor (an average score of 2.34). The notion of wishing to belong to some social group turned out to have less relevance to the participants (an average of 1.37). The third group of factors influencing the students' motivation toward employment included those elements connected with fulfilling their need for self-development. Within this group of factors, a very significant role in motivating the students at work was played by the possibility to use your skills and knowledge (a score of 2.47) as well as the ability to express yourself through the realization of working tasks (an average score of 2.16). After analyzing the differences in assigning importance to individual factors motivating students toward future professional employment, it could be noted that they are not very clear cut. The students both from Lithuania as well as from Poland admitted that their motivation toward employment would be connected with material factors such as attractive working conditions and salary level. According to them, good working atmosphere, a factor being social in character, plays an important role in 
building motivation for work but it is less significant than material issues. The Lithuanian students also point to the possibility to use their own skills and knowledge as a factor that is equally important as good working atmosphere in the process of shaping their attitudes to work. For both groups, the least significant motivator is the wish to belong to some social group.

\section{Conclusion}

The research conducted among students from Poland and Lithuania exposed some differences in attitudes toward future professional employment. These differences are especially apparent in relation to the assessment of their own skills gained during the course of study. The students from Poland feel that they are decidedly better prepared for employment than their peers from Lithuania when it comes to: application experience, specialty experience, selfreliance, a sense of responsibility and creativeness. In contrast, the Lithuanian students assess their skills of tolerance to criticism, subject knowledge and goal understanding in terms of preparation for future employment higher that their Polish counterparts.

When we consider the division of skills into task related, people related, analytical and self-related, it could be concluded that the students from Poland most highly value those skills from the first three categories, while the students from Lithuania those from the last group - self related.

When it comes to motivation as an element of attitude toward future employment, it could be noted that material factors are the most important motivator for the students of both countries. However, it is clearly visible that the students from Lithuania put greater emphasis on motivational factors connected with satisfying their social needs and those concerning selffulfilment.

The smallest differences in attitudes toward future employment between the students from Poland and Lithuania occur in perceiving the influence of individual environmental elements on their future professional career. However, the factor concerning experience was much more important for the Polish than Lithuanian students in shaping their attitudes toward work. The experience in general seems to be a crucial determinant of young Poles' future work attitudes.

The above research findings indicate the workplace expectations of tertiary education graduates in the analyzed countries. Beside the financial motivation, they greatly appreciate the prospects of getting experience in Poland and possibilities of self-fulfilment in Lithuania. 
Vilmante Kumpikaite - Valiūniene, Ewa Rollnik-Sadowska, Ewa Glińska. Education and Future Work Attitudes of Students in Poland and Lithuania: a Comparative Analysis

\section{References}

Analoui, F. (1993). Skills of management. In J.W.Cusworth \& T.F. Franks (Eds), Managing Projects in Developing Countries. Longman.

Breckler, S. J. (1984). Empirical Validation of Affect, Behavior, and Cognition as Distinct Components of Attitude," Journal of Personality and Social Psychology, 1191-1205.

Bryner, J. (2010). Big Generation Gaps in Work Attitudes Revealed, Live Science http://www.livescience.com/6195-big-generation-gaps-work-attitudes-revealed.html.

Daft, R.L., Sormunen, J., \& Parks, D. (1988). Chief executive scanning, environmental characteristics, and company performance: an empirical study, Strategic Management Journal 9, 123-139.

European Commission (2014). Population ageing in Europe: facts, implications and policies, Luxembourg: Publications Office of the European Union, doi:10.2777/60452.

Eurostat (2015). Fertility statistics. http://ec.europa.eu/eurostat/statistics-explained/ index.php/Fertility_statistics

Eurostat (2016). Annual expenditure on public and private educational institutions compared to GDP per capita. http://ec.europa.eu/eurostat/data/database

Hirschi, A., Lee, B., Porfeli, E.J., \& Vondracek, F.W. (2013). Proactive motivation and engagement in career behaviors: Investigating direct, mediated, and moderated effects. Journal of Vocational Behavior, 83(1), 31-40. doi:10.1016/J.Jvb.2013.02.003.

Fulton, O., Santiago, P., Edquist,Ch., El-Khawas, E., \& Hackl, E. (2007). OECD Reviews of Tertiary Education. Poland. OECD Publishing.

Kanfer, R., Chen, G., \& Pritchard, R. D. (2008). The three C's of work motivation: Content, context, and change. In R. Kanfer, G. Chen, \& R. D. Pritchard (Eds.), Work motivation: Past, present, and future. New York: Routledge, Taylor \& Francis Group.

Kumpikaite-Valiūniene V., Aslan I., Glinska E., Ramirez A. M., (2016). Students' Attitude to Job Performance: Intercultural Study, Engeenering Economics 27 (2) (in print).

Maslow, A.H. (1967). A theory of metamotivation: the biological rooting of the value-life. Journal of Humanistic Psychology, 7, 143-153.

Parker, S.K., Bindl, U.K., \& Strauss, K. (2010). Making things happen: A model of proactive motivation. Journal of Management, 36(4), 827-856. http://dx.doi.org/ $10.1177 / 0149206310363732$

Parker, S.; \& Bindl, U.K. (2010). Feeling good and performing well? Psychological engagement and positive behaviors at work. Handbook of Employee Engagement: Perspectives, Issues, Research and Practice. ed. / Simon L. Albrecht. Cheltenham, United Kingdom: Edward Elgar Publishing,. 385-398.

Robbins S.P., \& Judge T.A. (2009). Organizational Behavior. Prentice Hall Inc.,New Jersey.

Valero, D. \& Hirschi, A. (2016). Latent profiles of work motivation in adolescents in relation to work expectations; goal engagement; and changes in work experiences, Journal of Vocational Behavior. doi:10.1016/j.jvb.2016.01.003.

Wahba, M.A \& Bridwell, L.G. (1976). Maslow Reconsidered: A Review of Research on the Need Hierarchy Theory. Organisational Behaviour and Human Performance, 15, 212 240.

Wołkonowski, J. (2015). Szkolnictwo wyższe na Litwie w okresie 1989 - 2014 - od interwencjonizmu do liberalizmu. Optimum. Studia Ekonomiczne, 3 (75). doi: 10.15290/ose.2015.03.75.13. 